\title{
EFEK ANTIBAKTERI EKSTRAK KULIT BUAH DELIMA (PUNICA GRANATUM) TERHADAP SHIGELLA DYSENTRIAE SECARA IN VITRO
}

\section{ANTIBACTERIAL EFFECT OF POMEGRANATE'S (PUNICA GRANATIUM) RIND EXTRACT AGAINST SHIGELLA DYSENTRIAE IN VITRO}

\author{
Teguh Prihantoro*, Rasjad Indra **, Sumarno *** \\ * Program Studi Pendidikan Dokter Fakultas Kedokteran Universitas Brawijaya Malang \\ ** Laboratorium Faal Fakultas Kedokteran Universitas Brawijaya Malang \\ *** Laboratorium Mikrobiologi Fakultas Kedokteran Universitas Brawijaya Malang
}

\begin{abstract}
Shigella dysentriae is the most common organisms which causes bacillary dysentery in developing countries with high mortality. Pomegranates (Punica granatum) have been used since a long time ago in folk medicine for several purposes. The antibacterial activity was linked to the presence of major phytocompounds like flavonoids, triterpenes, phenols, and ellagitannin. The aim of this experimental study was to evaluate the antibacterial effect of Pomegranate's (Punica Granatum) rind extract against Shigella dysentriae and to determine the relationship between concentrations of Pomegranate's rind extract with the growth of Shigella dysentriae in vitro. Antimicrobial effect was determined by tube dilution method. This consists of determination of Minimum Inhibitory Concentrations (MICs), and Minimum Bactericidal Concentrations (MBCs). The concentrations of Pomegranate's (Punica Granatum) rind extract were $0.8 \%, 1 \%, 1.2 \%, 1.4 \%$, $1.6 \%$, and $1.8 \%$. At low extract concentration (0.8\%) bacterial growth was delayed, while at higher extract concentration (1.8\%) bacterial growth was elimanated (ANOVA, $p=0.000$, Regression $R=-0.901$ ). The Minimum Inhibitory Concentrations (MICs) value could not be obtained, while the Minimum Bactericidal Concentrations (MBCs) value on $1.8 \%$. The conclusion of this experimental study is that pomegranate's rind extract has antibacterial effect against Shigella dysentriae.
\end{abstract}

key words: Shigella dysentriae, Pomegranate's rind extract, antibacterial activity

\section{PENDAHULUAN}

Shigella merupakan penyebab utama terjadinya disentri basiler, yaitu suatu penyakit yang ditandai dengan nyeri perut hebat, diare yang sering dan sakit, dengan volume tinja sedikit disertai dengan adanya lendir dan darah (1). Kebanyakan penyakit ini terjadi pada anak umur 1-10 tahun dan menjadi suatu masalah kesehatan yang sangat penting untuk diperhatikan, karena pada penyakit ini, penderita dapat mengalami diare yang hebat hingga 20-30 kali sehari yang dapat mengakibatkan terjadinya dehidrasi, dan bila tidak segera diatasi dehidrasi tersebut akan dapat mengakibatkan terjadinya kematian (2).

Di Amerika Serikat, gejala disentri basiler lebih banyak disebabkan oleh Shigella sonnei dibandingkan spesies lainnya. Pada tahun 1989, terdapat 25.010 kasus shigellosis yang dilaporkan ke Center of Disease Control (CDC), 80\% disebabkan oleh Shigella sonnei, sisanya terutama disebabkan oleh Shigella flexneri, sedangkan Shigella dysenteriae dan Shigella boydii menyebabkan

Jurnal Kedokteran Brawijaya,Vol. XXII, No. 3, Desember 2006 Korespondensi: Sumarno; Laboratorium Mikrobiologi Fakultas Kedokteran Unibraw Malang; Jl. Veteran Malang 65145; 0341 - 580993 ext 128 kurang dari $2 \%$ dari seluruh infeksi Shigella di Amerika Serikat (3). Hal ini berkebalikan dengan kejadian di negaranegara yang sedang berkembang yang higien dan sanitasinya jelek, Shigella dysenteriae dan Shigella boydii merupakan spesies yang lebih sering diisolasi, diikuti Shigella flexneri dan Shigella sonnei (1).

Prognosa disentri basiler menjadi lebih buruk apabila bakteri penyebabnya adalah Shigella disentriae dan terjadi pada anak-anak (1). Diperkirakan dari sekitar 140 juta kasus shigellosis pada anak dengan usia dibawah 5 tahun di dunia setiap tahunnya, sekitar 600.000 diantaranya meninggal dunia (4). Dengan demikian dapat dikatakan bahwa disentri basiler merupakan masalah kesehatan yang serius dan harus diberikan penanganan yang tepat. Tindakan yang harus segera diberikan kepada penderita shigellosis adalah mencegah terjadinya dehidrasi, serta pemberian obat antibakteri sebagai terapi kausatif, akan tetapi, dengan semakin banyaknya ditemukan kasus resistensi bakteri terhadap antibiotik, pemakaian antibiotik harus tetap diwaspadai dan diperlukan suatu alternatif terapi sebagai pilihan terapi kausatif terhadap terjadinya disentri basiler ini.

Delima telah lama dimanfaatkan buahnya untuk dikonsumsi dan beberapa bagian dari tanaman Delima dimanfaatkan sebagai obat berbagai penyakit. Semua 
bagian tanaman bersifat antivirus, dan antibakteri. Sebagai antibakteri, beberapa senyawa fitokimia dilaporkan dapat menghambat pertumbuhan bakteri penyebab penyakit. Salah satunya adalah kandungan ellagitannin dari tanaman Delima (Punica granatum), yang terutama terdapat pada bagian kulit buahnya (5). Selain ellagitannin, kulit buah Delima juga mengandung flavonoid, triterpenes, dan phenol yang terbukti memiliki efek antibakteri terhadap Escherichia coli (6).

Tujuan dilakukannya penelitian ini adalah untuk mengetahui efek antibakteri ekstrak kulit buah Delima terhadap Shigella dysentriae secara invitro dan mengetahui korelasi antara perbedaan konsentrasi ekstrak kulit buah Delima yang diberikan dengan jumlah koloni Shigella dysentriae yang tumbuh.

\section{METODE}

Penelitian ini menggunakan studi true experimental in vitro dengan menggunakan metode tube dilution test untuk mengetahui potensi ekstrak kulit buah Delima (Punica granatum) sebagai antibakteri terhadap Shigella disentriae. Tube dilution test meliputi dua tahap, yaitu penentuan KHM (Kadar Hambat Minimum) dan KBM (Kadar Bunuh Minimum). Kadar Hambat Minimal (KHM) adalah kadar atau konsentrasi minimal larutan ekstrak kulit buah Delima yang mampu menghambat pertumbuhan kuman uji (Shigella dysentriae), ditandai dengan lebih jernihnya larutan pada tabung perlakuan apabila dibandingkan dengan tabung kontrol bahan.

Kadar Bunuh Minimal (KBM) adalah kadar atau konsentrasi minimal larutan ekstrak kulit buah Delima yang mampu membunuh kuman uji (Shigella dysentriae), ditandai oleh penurunan jumlah koloni pada media NAP dengan jumlah koloni kurang dari $0,1 \%$ original inokulum (7).

Dalam penelitian ini akan digunakan 6 konsentrasi ekstrak kulit buah Delima yang berbeda, 1 kelompok kontrol bakteri, dan 1 kelompok kontrol bahan. Untuk masingmasing perlakuan dilakukan empat kali pengulangan. Ekstrak kulit buah Delima adalah larutan hasil ekstraksi ethanol kulit buah Delima. Konsentrasi ekstrak adalah kadar kulit buah Delima yang telah mengalami ekstraksi dan pengenceran dengan menggunakan metode tube dilution test.

Variabel bebas dalam penelitian ini adalah konsentrasi ekstrak kulit buah Delima yang digunakan, yaitu konsentrasi $1,8 \%, 1,6 \%, 1,4 \%, 1,2 \%, 1 \%$, dan $0,8 \%$. Sedangkan variabel tergantung dalam penelitian ini adalah tingkat kekeruhan tabung uji dan jumlah koloni Shigella dysentriae yang tumbuh pada NAP (Nutrient Agar Plate).
Jumlah koloni adalah jumlah koloni kuman Shigella dysentriae yang tumbuh pada media NAP (Nutrient Agar Plate) setelah dilakukan inkubasi selama 18-24 jam.

Sebelum diberi perlakuan, bakteri uji terlebih dahulu diidentifikasi karakteristiknya. Meliputi pengamatan sifat koloni pada medium Mac Conkey, pewarnaan Gram, Inokulasi pada TSI (Triple Sugar Iron) agar, uji IMVIC (Indol Methylred Vogesproskoer Citrat) dan Uji kepekaan terhadap Trimetoprim-sulfametoxazole, Ampicillin, Nalidixic acid, dan Ciprofloxacin. Selanjutnya dikelompokkan menjadi 8 kelompok perlakuan yang merupakan campuran antara ekstrak kulit buah Delima (konsentrasi tertentu) dengan bakteri Shigella dysentriae (kerapatan 10 bakteri/ml) (6) sebagai berikut:

1. Kontrol bahan ( $0 \%$ ekstrak kulit buah Delima)

2. $0,8 \%$ ekstrak kulit buah Delima

3. $1 \%$ ekstrak kulit buah Delima

4. $1,2 \%$ ekstrak kulit buah Delima

5. $1,4 \%$ ekstrak kulit buah Delima

6. $1,6 \%$ ekstrak kulit buah Delima

7. $1,8 \%$ ekstrak kulit buah Delima

8. Kontrol kuman (100\% ekstrak kulit buah Delima)

Kadar Hambat Minimal dari ekstrak kulit buah Delima ditentukan dengan melakukan pengamatan kekeruhan larutan pada tabung setelah dilakukan inkubasi selama 1824 jam. Sedangkan Kadar Bunuh Minimal ditentukan setelah dilakukan penghitungan jumlah koloni yang tumbuh pada agar padat NAP, yang merupakan hasil stricking larutan pada tiap tabung perlakuan. Data yang diperoleh dari penghitungan jumlah koloni selanjutnya dianalisa statistik dengan menggunakan program SPSS 12.

\section{HASIL PENELITIAN}

Dari identifikasi, didapatkan hasil bahwa bakteri yang digunakan memiliki ciri: koloni bakteri pada Mac Conkey berbentuk bulat, konveks, dengan tepi yang utuh dan tidak berwarna (pucat), berbentuk batang ramping, Gram negatif, tidak membentuk spora, pada TSI (alkali/asam, gas-), Indole (+), Methyl red (+), Voges Proskauer(-), Citrat (-), Motilitas (-), resisten terhadap ampicillin.

Kadar Hambat Minimal ekstrak kulit buah Delima pada penelitian ini tidak dapat ditentukan, karena larutan campuran ekstrak dan bakteri berwarna gelap dan keruh. Hasil penentuan kekeruhan larutan ini dapat dilihat pada Gambar 1.

Kadar Bunuh Minimal ekstrak kulit buah Delima terhadap Shigella dysentriae adalah konsentrasi 1.8\%. Hasil stricking kelompok perlakuan dapat dilihat pada Gambar 2. 


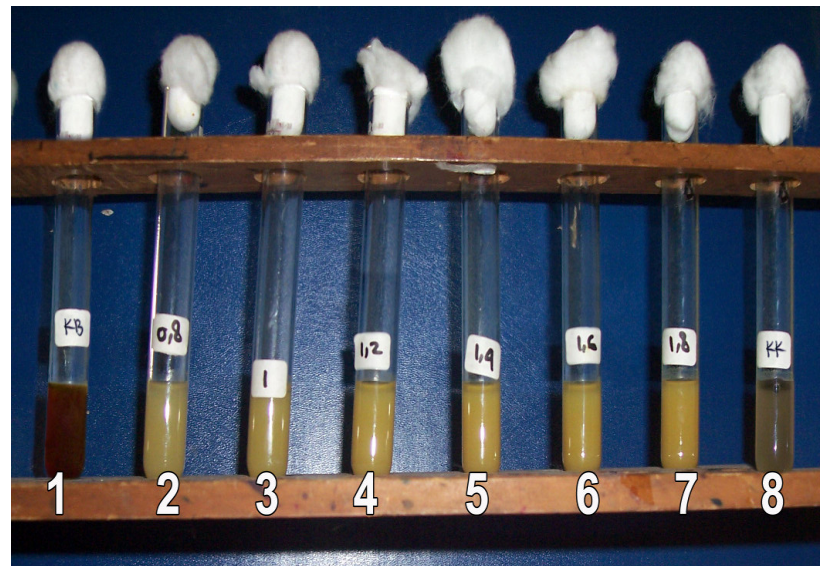

Gambar 1 Penentuan Kadar Hambat Minimum (KHM)

Keterangan :

1. Kontrol bahan

2. 0,8\% ekstrak kulit buah Delima+ 1cc bakteri Shigella dysentriae

3. $1 \%$ ekstrak kulit buah Delima $+1 \mathrm{cc}$ bakteri Shigella dysentriae

4. 1,2\% ekstrak kulit buah Delima+ 1cc bakteri Shigella dysentriae

5. 1,4\% ekstrak kulit buah Delima+ 1cc bakteri Shigella dysentriae

6. 1,6\% ekstrak kulit buah Delima+ 1cc bakteri Shigella dysentriae

7. 1,8\% ekstrak kulit buah Delima+ 1cc bakteri Shigella dysentriae

8. Kontrol kuman

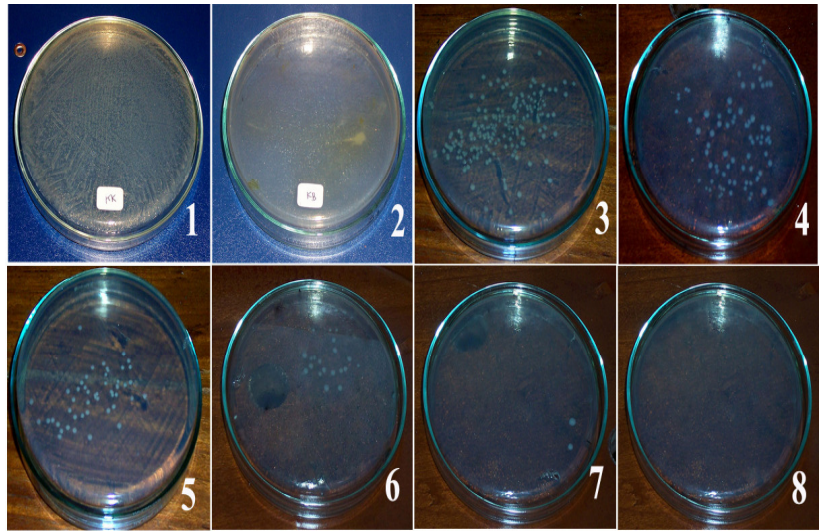

Gambar 2 Koloni yang Tumbuh pada NAP

Keterangan :

1. Kontrol kuman

2. Kontrol bahan

3. Konsentrasi ekstrak $0,8 \%$

4. Konsentrasi ekstrak $1 \%$

5. Konsentrasi ekstrak $1,2 \%$

6. Konsentrasi ekstrak $1,4 \%$

7. Konsentrasi ekstrak $1,6 \%$

8. Konsentrasi ekstrak $1,8 \%$

Hasil penghitungan jumlah koloni yang tumbuh dapat dilihat pada Tabel 1.
Tabel 1 Jumlah Koloni yang Tumbuh

\begin{tabular}{cc}
\hline Konsentrasi & Rata-rata \pm SD \\
\hline \hline $0,80 \%$ & $144 \pm 36,579$ \\
$1,00 \%$ & $74 \pm 5,944$ \\
$1,20 \%$ & $42,5 \pm 8,103$ \\
$1,40 \%$ & $29,75 \pm 10,532$ \\
$1,60 \%$ & $2 \pm 2,160$ \\
$1,80 \%$ & 0 \\
\hline
\end{tabular}

Kurva korelasi antara konsentrasi ekstrak kulit buah delima dengan jumlah koloni yang tumbuh dapat dilihat pada Gambar 3.

lı Imlah Kolnni

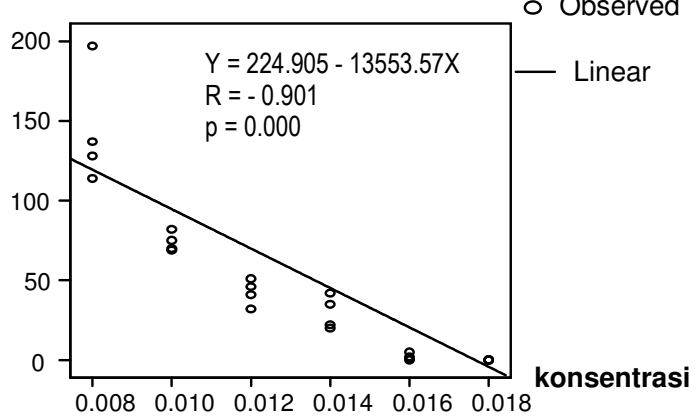

Gambar 3. Kurva Estimasi Hubungan Konsentrasi Ekstrak terhadap Jumlah Koloni

Jumlah koloni pada kontrol kuman tidak dapat dihitung karena jumlahnya sangat banyak. Oleh karena itu, agar jumlah koloni pada kontrol kuman dapat dihitung, maka diencerkan hingga 1000 kali, kemudian baru dilakukan stricking pada NAP. Hasil stricking dari pengenceran kontrol kuman ini didapatkan jumlah rata-rata koloni sebanyak 81 dengan standar deviasi sebesar 14.49, berarti pada kontrol kuman didapatkan rata-rata koloni sebanyak 81000. Pada kelompok kontrol bahan tidak didapatkan adanya koloni bakteri yang tumbuh. Hal ini berarti bahwa larutan ekstrak kulit buah Delima yang digunakan dalam penelitian ini tidak terkontaminasi oleh bakteri apapun.

Penghitungan jumlah koloni pada original inoculum didapatkan jumlah koloni rata-rata adalah 236 koloni. Jadi Kadar Bunuh Minimum (KBM) dari ekstrak kulit buah Delima terhadap Shigella dysentriae adalah konsentrasi $1.8 \%$ karena jumlah koloni pada konsentrasi tersebut $<0.1 \%$ dari original inoculum.

Dari analisis SPSS didapatkan hasil uji ANOVA dengan $p<0,05$, Pada uji korelasi didapatkan nilai $R=-$ 0,901 , dan persamaan regresi $\mathrm{y}=224,905-13553,57 \mathrm{x}$ (y adalah jumlah koloni yang tumbuh, dan $\mathrm{x}$ adalah besarnya konsentrasi ekstrak kulit buah delima dalam larutan campuran ekstrak kulit buah delima dan bakteri uji). 


\section{DISKUSI}

Penelitian ini dilakukan untuk mengetahui efektivitas ekstrak kulit buah Delima sebagai antibakteri terhadap Shigella dysentriae. Metode yang digunakan adalah metode dilusi tabung yang terdiri dari dua tahap, yaitu penentuan Kadar Hambat Minimum (KHM) dan penentuan Kadar Bunuh Minimum (KBM). KHM dari ekstrak kulit buah Delima tersebut ditentukan dengan cara membandingkan kekeruhan larutan pada tabung kelompok kontrol kuman dengan kelompok yang lain. Sedangkan penentuan Kadar Bunuh Minimum dilakukan dengan cara menghitung jumlah koloni yang tumbuh pada NAP (7).

Untuk mendapatkan efek maksimal dari zat aktif yang terdapat pada kulit buah Delima ini, dilakukan metode ekstraksi etanol. Metode ini berdasarkan pada penelitian yang dilakukan oleh Voravuthikunchai, dkk (2005), yang melakukan penelitian efek antibakteri beberapa metode ekstraksi kulit buah Delima terhadap Escherichia coli. Dari penelitiannya didapatkan hasil bahwa metode ekstraksi etanol kulit buah Delima menunjukkan efek yang paling baik dalam menghambat pertumbuhan Escherechia coli apabila dibandingkan dengan menggunakan metode ekstraksi dengan air mendidih maupun ekstraksi dengan menggunakan kloroform (8).

Pada penelitian ini, setelah dilakukan proses ekstraksi etanol dari kulit buah Delima, didapatkan hasil berupa larutan pekat yang berwarna coklat gelap. Warna larutan yang gelap mempersulit dalam mengamati kejernihan tabung-tabung yang merupakan campuran antara bakteri uji dengan larutan ekstrak kulit buah Delima. Pengamatan kejernihan larutan ini sebenarnya bermanfaat dalam menentukan Kadar Hambat Minimum dari larutan ekstrak kulit buah Delima terhadap pertumbuhan bakteri uji (Shigella dysentriae). Warna coklat pada larutan ekstrak tersebut kemungkinan disebabkan karena banyaknya kandungan tannin pada kulit buah Delima. Hasil yang sama juga didapatkan pada penelitian yang dilakukan oleh Seeram, dkk (2004) untuk mendapatkan ekstrak murni tannin dari kulit buah Delima. Pada penelitiannya tersebut didapatkan hasil ekstrak berupa serbuk tannin yang berwarna coklat gelap (9).

Dengan adanya warna yang gelap pada penelitian ini menyebabkan Kadar Hambat Minimum dari ekstrak kulit buah Delima terhadap pertumbuhan Shigella dysentriae, tidak dapat ditentukan, sehingga untuk mengetahui kadar hambat minimal dari ekstrak kulit buah Delima terhadap Shigella dysentriae sebaiknya digunakan metode lain, seperti difusi cakram atau metode $E$ test (1).

Hasil penghitungan jumlah koloni pada penelitian ini dapat dilihat pada tabel 1 , dari tabel tersebut dapat disimpulkan bahwa pemberian ekstrak kulit buah Delima berpengaruh terhadap penurunan jumlah bakteri. Hal ini dibuktikan dengan hasil analisa SPSS yang menunjukkan hasil signifikan (ANOVA, $p=0,000$ ). Jumlah koloni yang tumbuh semakin menurun dengan meningkatnya konsentrasi yang diberikan (Regresi, $R=-0,901$ ), dan efek dari ekstrak kulit buah Delima ini maksimal pada konsentrasi $1,8 \%$, yang semua bakteri mengalami kematian pada konsentrasi ini. Pengaruh ekstrak kulit buah Delima terhadap kematian bakteri tersebut disebabkan karena pada larutan ekstrak kulit buah Delima terdapat beberapa zat aktif yang dapat berfungsi sebagai antibakteri, diantaranya adalah flavonoid, triterpenes, phenol dan tannin (8).

Flavonoid merupakan suatu bahan yang mempunyai struktur fenol dengan satu carbonil group (10). Senyawa ini telah diketahui disintesis oleh tanaman dalam responnya terhadap infeksi mikroba (11). Aktivitas flavonoid kemungkinan disebabkan oleh kemampuannya untuk membentuk kompleks dengan protein ekstraseluler maupun yang terlarut, serta dapat membentuk kompleks dengan dinding sel. Semakin lipofilik suatu flavonoid, kemampuannya dalam merusak dinding sel dari bakteri akan semakin kuat (11). Catechin merupakan golongan flavonoid yang telah banyak dibuktikan manfaatnya oleh beberapa peneliti dalam peranannya sebagai bahan antibakteri. Pada penelitian yang dilakukan oleh Borris (1996) didapatkan hasil bahwa catechins dari teh hijau dapat menginaktivasi cholera toxin dari Vibrio cholera (12). Dan pada penelitian Nakahara, dkk (1993) juga dibuktikan bahwa catechin dari teh oolong terbukti dapat menghambat enzim glucosyltransferase dari bakteri Staphilococcus mutans yang pada akhirnya dapat menyebabkan kematian pada bakteri tersebut (13). Pada kulit buah Delima terdapat flavonoid dari golongan gallocatechin yang kemungkinan juga berperan sebagai penyebab kematian bakteri Shigella dysentriae pada penelitian ini (12).

Triterpenes merupakan senyawa yang dapat memberikan bau atau aroma khas pada tanaman (11). Walaupun mekanisme kerja triterpenes sebagai bahan antibakteri belum diketahui dengan baik, akan tetapi diduga terlibat dalam perusakan membran sel oleh senyawa lipofilik (10).

Bahan aktif lainnya yang berperan sebagai penyebab kematian bakteri dalam penelitian ini adalah dari golongan senyawa fenol. Mekanisme yang dianggap bertanggung jawab terhadap toksisitas fenol pada mikroorganisme meliputi inhibitor enzim oleh senyawa yang teroksidasi, kemungkinan melalui reaksi dengan gugus sulfhidril atau melalui interaksi non-spesifik dengan protein (7). Hasil penelitian yang dilakukan oleh Retno Sudewi (1992) menunjukkan bahwa kandungan fenol dalam daun salam secara in vitro terbukti dapat menghambat pertumbuhan Staphylococcus aureus dan Escherechia coli (14).

Bahan antibakteri terbanyak yang terdapat pada kulit buah Delima adalah golongan tannin, terutama kelompok 
ellagitannin (sekitar 26\%) (15). Senyawa ini mampu menghambat enzim DNA-topoisomerase, dengan dihambatnya aktifitas enzim ini, akan mengakibatkan terhambatnya proses replikasi bakteri tersebut (8). Keberadaan dari beberapa bahan yang memilki sifat antibakteri tersebut memberikan efek sinergis terhadap menurunnya jumlah Shigella dysentriae dalam penelitian ini. Ellagitannin memiliki kemampuan untuk menghambat pertumbuhan dan replikasi, sedangkan senyawa antibakteri yang lainnya memiliki kemampuan untuk merusak dinding sel dari bakteri. Dengan rusaknya dinding sel dari bakteri ini akan mengakibatkan keluarnya substansi seluler dari bakteri tersebut dan akan menyebabkan kematian pada bakteri.

\section{KESIMPULAN}

1. Secara in vitro, ekstrak kulit buah Delima memiliki efek antibakteri terhadap Shigella dysentriae. Kadar Hambat Minimum (KHM) dari ekstrak kulit buah Delima tidak dapat ditentukan, sedangkan Kadar Bunuh Minimum (KBM) sebesar 1,8\%.

2. Terdapat korelasi antara perbedaan konsentrasi ekstrak kulit buah Delima yang diberikan dengan

\section{DAFTAR KEPUSTAKAAN}

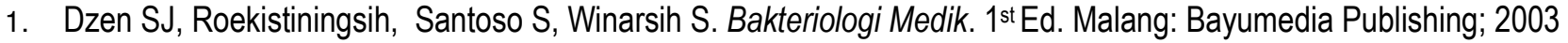

2. Hembing. Jangan Anggap Remeh Disentri. Online [www]. 2006 (http:// www. rsud. kebumen. go. id/ modules. php?op = modload $\&$ name $=$ News\&file $=$ article \&sid $=63$, diakses tanggal 29 april 2006)

3. Supardi I dan Sukamto. Mikrobiologi Dalam Pengolahan Dan Keamanan Pangan. Bandung: Penerbit Alumni; 1999.

4. Gerald. Diseases Caused By Gram-Negative Enteric Bacilli in Harrison Principal of Internal Medicine $15^{\text {th }}$ Edition. USA: McGraw Hill Company Inc;1996

5. Henriette's Herbal. Granatum (U.S.P) - Pomegranate. Online [www]. 2000 ( http:// www. ibiblio. org/ herbmed/ eclectic/ kings/ punica. html, diaskes tanggal 12 April 2006)

6. Supayang Voravuthikunchai, Treechada Shirirak, Surasak Limsuwan, Thanomjit Supawita,Tetsuya lida, Takehi Honda. Inhibitory Effects Of Active Compounds From Punica Granatum Pericarp On Verototoxin Production By Enterohemorrhagic Escherichia. 2005. Coli157:H7. (online) (http:/jhs.pharm.or.jp/51(5)/51_590.pdf, diakses tanggal 12 April 2006).

7. Pioneerherbs. Punica Granatum. 2000. (online)(http://www.pioneerherbs.com/punica_granatum.htm, diakses tanggal 12 April 2006)

8. Jawetz E, JL Melnick, EA Aldelberg, G Bonang. Mikrobiologi untuk Profesi Kesehatan. Edisi 16. Jakarta : EGC; 1996.

9. Coli157:H7.(online)(http:/jhs.pharm.or.jp/51(5)/51_590.pdf\#search=\%22inhibitory $\% 20$ effect $\% 20$ of $\% 20$ active $\% 20$ compo unds $\% 20$ from $\% 20$ punica\%20granatum\%20filetype\%3Apdf\%20, diakses tanggal 20 April 2006)

10. Marjorie Murphy Cowan. Plant Products as Antimicrobial Agent. (online)(http:/www.asmusa.org, diakses tanggal 6 Agustus 2006)

11. Yolanda LatraViata Aginza. Senyawa Antibakteri dari Tanaman. (online) (http://ginanjar.tv/web/content.php?article.66, diakses tanggal Mei 2005)

12. Sydney M Finegold, Ellen Jo Baron. Bailey \& Scott's Diagnostic Microbiology $7^{\text {th }}$ Edition. Missoury: The Cv Mosby Company; 1986

13. N. Seeram, R Lee, M Hardy, D Heber. Rapid Large Scale Purification Of Ellagitannins From Pomegranate Husk, A ByProduct Of The Commercial Juice Industry. (online) (www.sciencedirect.com, diakses tanggal 19 juli 2006)

14. Borris Rp. Natural Products Research: Perspectives from A Major Pharmaceutical Company. (online) (http:/www.ncbi.nlm.nih.gov/entrez/wuery.fcgi?cmd=Retrieve\&db=PubMed\&dopt=Abstract\&list_uids=9213624, diakses tanggal 6 Agustus 2006). 
15. Nakahara K, S Kawabata, H Ono, K Ogura, T Tanaka, T Ooshima, and S Hamada. Inhibitory Effect Of Oolong Tea Polyphenols On Glucosyltransferases Of Mutans Streptococci. Online [www]. 1993 (http://cmr.highwire.org/ cgi/ijlink?linkType=ABST \&journalCode=aem\&resid=59/4/968, diakses tanggal 29 maret 2006)

16. Anonymous. Renaissance Herbs. (online) (http://www.renaissanceherbs .com/products/Pomegranate40PIS.pdf\#search=\%22pomegranate $\% 2040 \% 20 \% 20 \% 22$ ellagic $\% 20$ acid $\% 20 \% 22 \% 20$ filety pe\%3Apdf\%22, diakses tanggal 29 april 2006).

17. Sudewi, Retno. Isolasi dan Uji Daya Antibakteri Minyak Atsiri Daun Salam (Eugeniapolyntha wight). Yogyakarta: FF UGM; 1992.

18. Levinson WE, Jewetz. Medical Microbiology and Immunology Sixth Edition. Singapore: Mc Graw-Hill company Inc; 2000. 

104 Jurnal Kedokteran Brawijaya, Vol. XXII, No. 3, Desember 2006 